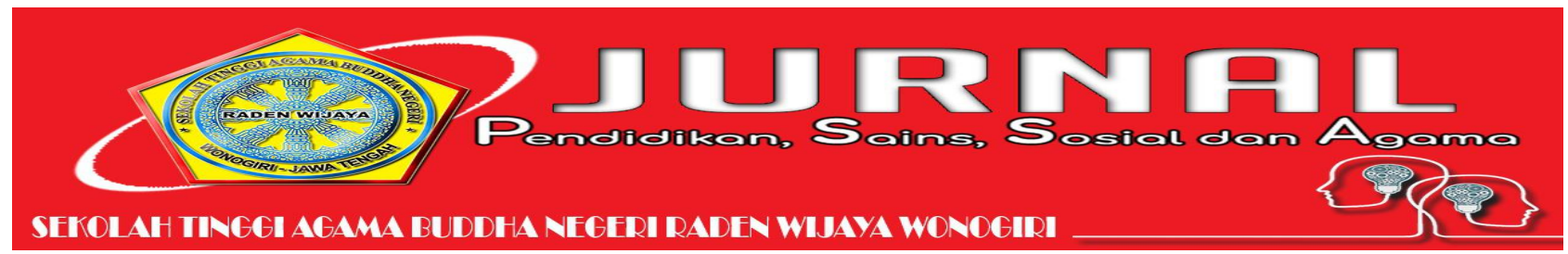

\title{
PENGARUH KETERSEDIAAN SARANA PRASARANA PEMBELAJARAN DAN KEAKTIFAN PESERTA DIDIK TERHADAP PRESTASI BELAJAR MATA PELAJARAN PENDIDIKAN AGAMA BUDDHA (Penelitian ex-post facto di Sekolah Menengah Pertama (SMP) Negeri 3 Kaloran)
}

\author{
Sri Yunani, Urip Widodo, Sukarti \\ Sekolah Tinggi Agama Buddha Negeri Raden Wijaya Wonogiri \\ yunayunania03@gmail.com
}

\begin{abstract}
Abstrak
Proses pembelajaran Pendidikan Agama Buddha di SMP N 3 Kaloran, belum maksimal selain ada masalah dari diri peserta didik, sarana prasarana pembelajaran juga kurang memadahi. Penelitian ini memiliki tujuan untuk: (1) Mengetahui pengaruh ketersediaan sarana prasarana pembelajaran terhadap prestasi belajar Pendidikan Agama Buddha (2) Mengetahui pengaruh keaktifan peserta didik terhadap prestasi belajar Pendidikan Agama Buddha, (3) Mengetahui pengaruh ketersediaan sarana prasarana pembelajaran dan keaktifan peserta didik terhadap prestasi belajar Pendidikan Agama Buddha. Desain penelitian ini adalah Penelitian kuantitatif dengan jenis penelitian ex-post facto. Populasi pada penelitian yaitu peserta didik beragama Buddha yang berjumlah 45 peserta didik, teknik dan instrumen pengumpulan data dilakukan dengan mengunakan kuesioner. Teknik analisis data menggunakan regresi linier berganda dengan bantuan program SPSS 25. Berdasarkan hasil penelitian dan analisis data dapat disimpulkan bahwa, ketersediaan sarana prasarana pembelajaran dan keaktifan peserta didik terdapat pengaruh yang signifikan terhadap prestasi belajar Pendidikan Agama Buddha di SMP N 3 Kaloran.
\end{abstract}

Kunci: Sarana Prasarana Pembelajaran, Kekatifan, Prestasi Belajar.

\section{Abstract}

The learning process of Buddhist education subject in SMP N 3 Kaloran is not optimal yet, besides the matters from the students themselves, the learning infrastructure is also inadequate. This study aims to: (1) Find out the influence of learning infrastructure availability to the learning achievement in Buddhist education subject (2) Find out the influence of students' activeness to the learning achievement in Buddhist education subject. (3) Find out the influence of learning infrastructure availability and students' activeness to the learning achievement in Buddhist education subject. This is an ex-post facto quantitative research. The populations were 45 Buddhist students. Techniques and instruments of data collection were carried out by using a questionnaire. Data analysis techniques used multiple linear regressions with SPSS 25. Based on the results and data analysis can be concluded that the availability of learning infrastructure and student's activeness have significant influences to the learning achievement of the Buddhist education subject in SMP N 3 Kaloran.

Key: Learning Infrastructure, Initiative, Learning Achievement. 


\section{Pendahuluan}

Pendidikan merupakan salah satu cara dalam pembentukan manusia yang pandai, memiliki moralitas yang baik dan mandiri. Pendidikan mempunyai peranan penting untuk menjamin keberlangsungan kehidupan peserta didik dimasa yang akan datang. Pendidikan bagi kehidupan manusia merupakan kebutuhan yang harus dipenuhi sepanjang hayat. Dunia pendidikan saat ini semakin berkembang, berbagai macam pembaharuan dilakukan agar dapat meningkatkan kualitas dan kuantitas dalam suasana belajar maupun proses pembelajaran. Meningkatkan kualitas pendidikan memerlukan berbagai terobosan, baik dalam pengembangan kurikulum, inovasi pembelajaran, pemilihan media pembelajaran dan pemenuhan sarana dan prasarana pendidikan. Proses belajar mengajar, akan mencapai tujuan apabila guru mampu membuat pembelajaran menjadi lebih inovatif. Selain itu mampu memotivasi peserta didik belajar secara optimal baik dalam belajar mandiri maupun dalam pembelajaran di kelas. Hal ini sesuai dengan Undang-undang Sistem Pendidikan Nasional No. 20 Tahun 2003, BAB 1 Pasal 1 yaitu: "Setiap satuan pendidikan wajib memiliki sarana yang meliputi perabot, peralatan pendidikan, media pendidikan, buku sumber belajar lainnya, bahan habis pakai, serta perlengkapan lain yang diperlukan untuk menunjang proses pembelajaran yang teratur dan berkelanjutan".

Pendidikan menjadi sarana utama yang perlu dikelola secara sistematis dan konsisten untuk memajukan kehidupan. Menurut Karsan dan Sulan (2017: 4) Pendidikan Agama Buddha adalah usaha sadar yang dilakukan secara terencana dan berkesinambungan dalam rangka mengembangkan kemampuan peserta didik untuk memperteguhkan keimanan dan ketakwaan kepada Tuhan Yang Maha Esa dan berakhlak mulia, serta peningkatan potensi spiritual sesuai ajaran Agama Buddha.

Kemampuan peserta didik dapat diperoleh dari pendidikan Agama Buddha yang ada di sekolah. Pendidikan Agama Buddha di sekolah dapat diterapkan dan diwujudkan dalam kehidupan sehari-hari, sehingga memberikan manfaat bagi diri sendiri dan lingkungan. Berdasarkan uraian di atas pendidikan merupakan proses pembelajaran yang diperoleh setiap peserta didik dalam hal mengerti, paham, dan lebih dewasa serta mampu membuat peserta didik lebih inovatif dan kritis dalam berpikir. Pendidikan Agama Buddha bermanfaat bagi peserta didik dikehidupan sehari-hari.

Peserta didik dapat mempraktikkan ajaran Sang Buddha dalam kehidupan sehari-hari. Proses belajar yang dialami oleh peserta didik ditandai dengan terjadinya perubahan dalam diri setiap individu, baik dalam aspek kognitif, aspek afektif maupun aspek psikomotor. Ketiga aspek tersebut kemudian menjadi parameter untuk mengetahui prestasi belajar peserta didik. Peningkatan mutu pendidikan tidak terlepas dari ketersedian fasilitas penunjang pembelajaran peserta didik berupa sarana dan prasarana di sekolah. Sarana pendidikan adalah peralatan dan perlengkapan yang secara langsung dipergunakan dan menunjang proses pendidikan, khususnya proses belajar mengajar, seperti gedung, ruangan kelas, meja, kursi, serta alat-alat dan media pengajaran (Mulyasa, 2003: 49).

Menurut Barnawi dan Arifin (2012: 47-48) Prasarana pendidikan adalah semua perangkat kelengkapan dasar yang secara tidak langsung 
menunjang pelaksanaan proses pendidikan di sekolah. Oleh karena itu sarana prasarana pembelajaran adalah seperangkat alat yang digunakan untuk menunjang pembelajaran. Pentingnya sarana prasarana untuk menunjang proses pendidikan di atur oleh Undang-undang Republik Indonesia Nomor. 20 tahun 2003 tentang Sistem Pendidikan Nasional "Setiap satuan pendidikan formal dan non formal menyediakan sarana dan prasarana yang memenuhi keperluan pendidikan sesuai dengan pertumbuhan dan perkembangaaan potensi peserta didik” (Redaksi Sinar Grafika, 2014: 61).

Proses belajar mengajar akan semakin sukses bila ditunjang dengan sarana prasarana sekolah yang memadai. Sarana prasarana yang memadai yaitu gedung yang terawat dengan baik, ruang kelas yang nyaman dan bersih, tersedianya tempat ibadah, perpustakaan yang lengkap dan tersedianya peralatan penunjang pembelajaran. Menurut Sanjaya (2010: 18) "Sarana belajar adalah segala sesuatu yang mendukung terhadap kelancaran proses pembelajaran".

Peningkatan mutu pendidikan di sekolah berkaitan langsung dengan prestasi belajar peserta didik. Keberhasilan pendidikan di sekolah dapat dilihat dari prestasi peserta didiknya. Peserta didik dalam proses pembelajaran harus aktif hal ini sangat penting dan perlu diperhatikan sehingga proses belajar yang ditempuh benar-benar memperoleh hasil yang optimal khususnya pada pendidikan Agama Buddha.

Prestasi belajar peserta didik dapat dipengaruhi oleh dua faktor. Faktor internal maupun faktor eksternal, faktor internal yang dapat mempengaruhi prestasi belajar yaitu: motivasi belajar peserta didik, gaya belajar, intensitas belajar, kondisi, tempat belajar, dan target belajar. Faktor eksternal yang mempengaruhi prestasi belajar salah satunya ketersediaan sarana prasarana pembelajaran (Slameto, 2010: 54).

Proses pembelajaran guru dapat mempengaruhi hasil belajar, dalam hal ini guru sebagai fasililator. Selain guru dan peserta didik, orang tua juga memiliki peranan yang tidak kalah penting. Orang tua memberikan motivasi dan sekolah memberi dukungan fasilitas untuk peserta didik, agar peserta didik memiliki minat belajar. Pelaksanaan pembelajaran dilakukan secara interaktif, inspiratif, menyenangkan, memotivasi peserta didik untuk berpartisipasi, kreatif, dan mandiri sesuai bakat minat.

Kegiatan pembelajaran yang ideal merupakan interaksi aktif antara guru dengan peserta didik. Tugas dan tanggung jawab utama seorang guru adalah mengelola pembelajaran dengan lebih efektif, dinamis, efisien dan positif, yang ditandai dengan adanya kesadaran dan keterlibatan aktif diantara dua subyek pembelajaran. Guru sebagai inisiator awal dan pengarah serta pembimbing, sedangkan pesera didik sebagai yang dipengaruhi dan terlibat aktif untuk memperoleh perubahan diri dalam pembelajaran. Keaktifan peserta didik merupakan salah satu prinsip utama dalam proses pembelajaran ideal.

Menurut Slameto (2010: 2) Belajar ialah suatu proses usaha yang dilakukan seseorang untuk memperoleh suatu perubahan tingkah laku yang baru secara keseluruhan, sebagai hasil pengalamannya sendiri dalam interaksi dengan lingkungannya. Keaktifan peserta didik merupakan salah satu prinsip utama dalam proses pembelajaran. Belajar merupakan berbuat, oleh karena itu tidak ada belajar tanpa aktivitas. 
Pengalaman belajar hanya dapat diperoleh jika peserta didik aktif berinteraksi dengan lingkungannya. Keaktifan peserta didik sangat penting dalam proses pembelajaran sebab pengetahuan, ketrampilan, dan sikap tidak dapat ditransfer begitu saja tetapi harus peserta didik yang mengolahnya terlebih dahulu.

Namun berdasarkan hasil studi pendahuluan melalui wawancara dengan guru Pendidikan Agama Buddha di SMP N 3 Kaloran pada tanggal 19 November 2019 diperoleh data bahwa ketersediaan sarana prasarana di SMP N 3 Kaloran belum memadai, sehingga proses pembelajaran belum maksimal. Proses pembelajaran di SMP N 3 Kaloran masih menggunakan papan tulis belum menggunakan Liquid Crystal Display (LCD) dan laptop. Pada proses pembelajaran guru pasti memerlukan sarana yang dapat mendukung kinerjanya sehingga pembelajaran dapat berlangsung dengan baik. Melalui dukungan sarana prasarana yang memadai, guru tidak hanya menyampaikan materi secara lisan, tetapi juga dengan tulisan dan peragaan sesuai dengan sarana pembelajaran yang dipersiapkan.

Proses pembelajaran Pendidikan Agama Buddha di SMP N 3 Kaloran tidak berlangsung seperti yang diharapkan. Proses pembelajaran guru memposisikan diri sebagai satu-satunya pusat informasi. Tidak ada interaksi timbal balik diantara guru dengan peserta didik. Guru tidak melibatkan peserta didik dalam mencari dan menghimpun informasi, tidak mengajak peserta didik untuk aktif bertanya atau aktif menyampaikan pendapatnya. Beberapa peserta didik mengeluh bosan dan mengantuk, diantaranya ada yang mengatakan belum paham dengan materi yang disampaikan. Menurut data yang diperoleh, hal tersebut merupakan akibat dari proses pembelajaran yang kurang menarik peserta didik dan kurang motivasi peserta didik untuk berpartisipasi aktif dalam pembelajaran. Pembelajaran yang monoton dapat menghambat kreatifitas dan kemandirian peserta didik, karena peserta didik hanya menerima informasi tanpa mencari tahu sendiri.

Prestasi belajar peserta didik dapat dipengaruhi oleh gaya belajar peserta didik, motivasi, minat peserta didik untuk belajar, kondisi fisik peserta didik maupun kondisi lingkungan, keaktifan peserta didik pada saat proses pembelajaran, dan target belajar yang akan dicapai. Namun kondisi di SMP N 3 Kaloran beberapa peserta didik pasif, kurang motivasi, tidak mengetahui tujuan belajar yang akan dicapai, dan minat belajarnya rendah, hal ini dapat mengakibatkan prestasi belajar peserta didik rendah. Keaktifan peserta didik dalam proses pembelajaran merupakan hal yang sangat penting dan perlu diperhatikan sehingga proses pembelajaran dapat berjalan optimal.

Berdasarkan informasi dari guru Pendidikan Agama Buddha bahwa guru Pendidikan Agama Buddha di SMP N 3 Kaloran memiliki kompetensi yang sesuai dengan persyaratan yang diperlukan. Guru Pendidikan Agama Buddha di SMP N 3 Kaloran memiliki standar pendidikan sarjana pendidikan Agama Buddha yang telah sesuai dengan bidang yang diajar. Namun kurang menguasai bidang Informasi Teknologi (IT). Menurut Musfah (2015: 27) Kompetensi merupakan kumpulan pengetahuan, perilaku, dan keterampilan yang harus dimiliki guru untuk mencapai tujuan pembelajaran dan pendidikan. Tujuan pendidikan nasional dapat diraih jika para guru telah benar-benar kompeten. Dalam 
perspektif kebijakan nasional, pemerintah telah merumuskan empat jenis kompetensi guru, sebagaimana tercantum dalam penjelasan Peraturan Pemerintah Nomor. 19 Tahun 2005 tentang Standar Nasional Pendidikan BAB VI tentang Standar Pendidik Dan Tenaga Kependidikan Pasal 28, yaitu: kompetensi pedagogi, kompetensi kepribadian, kompetensi sosial, dan kompetensi profesional (Rusidi, 2009: 117).

Kondisi di SMP N 3 Kaloran, menunjukkan bahwa ada permasalahan saat guru mengajar, sebagian peserta didik tidak serius dan terlihat bosan dalam mengikuti proses pembelajaran. Hal ini terlihat ketika guru menjelaskan, masih banyak peserta didik yang berbicara dengan temannya, selain itu peserta didik kurang fokus pada materi yang disampaikan oleh guru. Ketika diminta untuk mengerjakan soal latihan, beberapa peserta didik tidak mengerjakan, ada juga yang berusaha mencontek temannya. Beberapa peserta didik ada yang bertanya seputar materi dan ada juga yang mencatat materi dari papan tulis yang ditulis oleh guru. Selama proses pembelajaran terkadang guru memberikan pertanyaan untuk mendorong peserta didik agar aktif dalam proses pembelajaran.

Proses pembelajaran Pendidikan Agama Buddha di SMP N 3 Kaloran, belum maksimal selain ada masalah dari diri peserta didik, sarana prasarana pembelajaran juga kurang memadahi. Peserta didik hanya belajar menggunakan papan tulis, buku tulis, bolpoin. Jumlah buku K-13 pendididkan Agama Buddha dan Budi Pekerti belum memadai di SMP N 3 Kaloran. Sarana prasarana di SMP N 3 Kaloran kurang memadai sehingga pembelajaran kurang berjalan dengan baik. Peserta didik sangat membutuhkan sarana prasarana untuk pembelajaran Pendidikan Agama Buddha.

Peserta didik kelas VII sejumlah 12 peserta didik, kelas VIII berjumlah 15 peserta didik dan kelas IX berjumlah 18 peserta didik. Sarana prasarana pembelajaran sangat dibutuhkan melihat jumlah siswa yang banyak. Proses belajar mengajar akan bermanfaat jika didukung dengan sarana prasarana dan interaksi antara peserta didik dan guru dalam menyampaikan materi pembelajaran. Berdasarkan wawancara dengan guru pendidikan Agam Buddha, bahwa peserta didik belum maksimal dalam hal Prestasi belajar. $\mathrm{N}$ menyatakan bahwa nilai peserta didik dapat dikatakan cukup, tetapi belum maksimal. Sekitar $25 \%$ peserta didik belum mencapai Kriteria Ketuntasan Minimal (KKM).

Sebagian lainnya ada yang hanya cukup dan beberapa sudah dapat dikatakan baik. KKM kelas IX yaitu 78 dan KKM kelas VII dan VIII yaitu 70, KKM kelas VII \& VII berbeda dengan kelas IX, karena kelas VII dan kelas VIII sudah K-13 dan IX masih mengunakan KTSP.

Sarana pendidikan adalah peralatan dan perlengkapan yang secara langsung dipergunakan dan menunjang proses pendidikan, khususnya proses belajar mengajar, seperti gedung, ruangan kelas, meja, kursi, serta alat-alat dan media pengajaran (Mulyasa, 2003: 49). Menurut Barnawi dan Arifin (2012: 47-48) Prasarana pendidikan adalah semua perangkat kelengkapan dasar yang secara tidak langsung menunjang pelaksanaan proses pendidikan di sekolah.

1. Klasifikasi Sarana Prasarana Pembelajaran Sarana pendidikan diklasifikasikan menjadi tiga macam, yaitu (1) habis tidaknya dipakai, (2) bergerak tidaknya pada saat 
digunakan, (3) hubungannya dengan proses belajar mengajar.

a. Dilihat dari habis tidaknya dipakai ada dua macam sarana pendidikan, yaitu:

1) Sarana pendidikan yang habis dipakai adalah segala bahan atau alat yang apabila digunakan habis dalam waktu yang relatif singkat. Contoh, kapur tulis, beberapa bahan kimia untuk praktik guru dan peserta didik. Selain itu, ada sarana pendidikan yang berubah bentuk, misalnya kayu, besi, dan kertas karton yang sering digunakan oleh guru dalam mengajar.

2) Sarana pendidikan tahan lama sarana pendidikan tahan lama adalah keseluruhan bahan atau alat yang dapat digunakan secara terus menerus dan dalam waktu yang relatif lama. Contoh, bangku sekolah, alat tulis, atlas, globe, dan beberapa peralatan olahraga (Yudi, 2012: 3).

b. Adapun sarana pendidikan yang ditinjau dari pendidikan bergerak tidaknya terbagi menjadi dua macam, yaitu:

1) Sarana pendidikan yang bergerak, yaitu sarana pendidikan yang dapat digerakkan atau dipindahkan sesuai dengan kebutuhan pemakainya, contoh: lemari, meja dan kursi, dan alat-alat praktik.

2) Sarana pendidikan yang tidak dapat bergerak yaitu, semua sarana pendidikan yang tidak dapat atau relatif sangat sedikit untuk dipindahkan. Contohnya: sekolah yang telah memiliki saluran dari perusahaan air minum (PDAM). Saluran kabel listrik, dan
Liquid Crystal Display (LCD) yang dipasang permanen.

c. Hubungannya dengan proses belajar mengajar ada dua jenis sarana pendidikan, yaitu:

1) Sarana pendidikan yang secara langsung dapat digunakan dalam proses pembelajaran. contoh: kapur tulis, atlas, globe, alat praktik, dan sarana pendidikan lainnya.

2) Sarana pendidikan yang secara tidak langsung berhubungan dengan proses belajar mengajar. Contohnya: lemari arsip di kantor sekolah merupakan sarana pendidikan yang tidak langsung digunakan oleh guru dalam proses belajar mengajar.

\section{Standarisasi Sarana dan Prasarana}

Standar sarana prasarana pendidikan dapat diartikan sebagai standar nasional pendidikan yang berkaitan dengan kriteria minimal tentang ruang belajar, tempat dan alat olahraga, tempat ibadah, perpustakaan, laboratorium, serta sumber belajar lainnya, yang diperlukan untuk menunjang proses pembelajaran, termasuk penggunaan teknologi informasi dan komunikasi. Menurut Peraturan Menteri Pendidikan Nasional Republik Indonesia Nomor 24 Tahun 2007, Standar Sarana Prasarana untuk SMP adalah memiliki gedung, ruang kelas, perpustakaan, laboratorium, ruang pimpinan, ruang guru, ruang tata usaha, tempat ibadah, ruang konseling, ruang UKS, ruang organisasi kesiswaan, jamban (toilet), gudang, ruang sirkulasi, tempat bermain atau berolahraga. 
3. Indikator Ketersediaan Sarana Prasarana

Indikator ketersediaan sarana dan Prasarana pendidikan yang harus diperhatikan menurut Wicaksono (2012:4547) adalah sebagai berikut:

a. Gedung sekolah meliputi kondisi serta kelengkapan bangunan.

b. Ruang belajar (ruang kelas dan Lab), meliputi tingkat kebisingan, penerangan, dan ventilasi, kenyamanan, ukuran, kebersihan, keamanan dan ketertiban, penataan.

c. Perpustakaan, meliputi kenyamanan dan kelengkapan bahan pustaka.

d. Media pembelajaran, meliputi ketersediaan serta penggunaan dalam proses belajar.

e. Alat-alat belajar (alat-alat tulis dan buku pelajaran), meliputi kondisi dan kelengkapan.

f. Fasilitas belajar di rumah meliputi ketersediaan ruang belajar.

Selain saran prasarana, prestasi belajar dapat dipengaruhi oleh keaktifan peserta didik. Menurut Rizwani dan Widayati (2012: 7) Keaktifan belajar peserta didik adalah aktifitas peserta didik dalam proses belajar mengajar yang melibatkan kemampuan emosional dan lebih menekankan pada kreativitas peserta didik, meningkatkan kemampuan, serta mencapai peserta didik yang kreatif dan mampu menguasai konsep-konsep. Menurut Sudjana (2005: 72) Keaktifan peserta didik dapat dilihat dari keikutsertaan peserta didik dalam melaksanakan tugas belajarnya, terlibat dalam memecahkan masalah, bertanya kepada peserta didik lain atau guru apabila tidak memahami persoalan yang dihadapi, berusaha mencari berbagai informasi yang diperlukan untuk memecahkan masalah, melatih diri dalam memecahkan masalah atau soal, serta menilai kemampuan diri sendiri dan hasilhasil yang diperoleh.

1. Faktor-faktor yang Mempengaruhi Keaktifan Pesrta Didik

Keaktifan peserta didik dalam proses pembelajaran dapat merangsang dan mengembangkan bakat yang dimilikinya, peserta didik juga dapat berlatih untuk berpikir kritis dan dapat memecahkan permasalahanpermasalahan dalam kehidupan sehari-hari. Keaktifan peserta didik dipengaruhi oleh beberapa faktor. Faktor yang mempengaruhi keaktifan belajar peserta didik Menurut Gagne dan Briggs (dalam Martinia, 2007: 84) yaitu, 1) Memberi motivasi atau menarik perhatian peserta didik, 2) Menjelaskan tujuan instruksional (kemampuan dasar kepada peserta didik), 3) Mengingatkan kompetensi belajar kepada peserta didik, 4) Memberikan stimulus (masalah, topik, dan konsep yang akan dipelajari), 5) Memberikan petunjuk kepada peserta didik cara mempelajari, 6) Memunculkan aktifitas, partisipasi peserta didik dalam kegiatan pembelajaran, 7) Memberikan umpan balik (feedback), 8) Melakukan tagihan-tagihan kepada peserta didik berupa tes sehingga kemampuan peserta didik selalu terpantau dan terukur, 9) Menyimpulkan setiap materi yang disampaikan diakhir pembelajaran.

2. Indikator Keaktifan Peserta Didik

Menurut Sujana (2004:

menyatakan keaktifan peserta didik dapat dilihat dari berbagai hal:

a. Turut serta melaksanakan tugas belajar peserta didik

b. Terlibat dalam pemecahan masalah 
c. Bertanya kepada peserta didik atau guru apabila tidak memahami persoalan yang dihadapi

d. Berusaha mencari berbagai informasi yang diperlukanuntuk pemecahan masalah

e. Melaksanakan diskusi sesuai dengan petunjuk guru

f. Menilai kemampuan peserta didik dan hasil yang diperoleh peserta didik

g. Melatih diri dalam memecahkan soal atau masalah yang sejenis

h. Kesempatan menggunakan atau menerapkan apa yang diperoleh dalam menyelesaikan tugas atau persoalan yang dihadapi.

Berdasarkan uraian di atas dapat disimpulkan bahwa keaktifan peserta didik dalam belajar merupakan segala kegiatan yang bersifat fisik maupun non fisik peserta didik dalam proses kegiatan belajar mengajar yang optimal sehingga dapat menciptakan suasana kelas menjadi kondusif dan interaktif. Keaktifan belajar adalah suatu kegiatan individu yang dapat membawa perubahan kearah yang lebih baik pada diri individu karena adanya interaksi antara individu dengan individu dan individu dengan lingkungan.

Prestasi belajar peserta didik dapat dipengaruhi oleh dua faktor. Faktor internal maupun faktor eksternal, faktor internal yang dapat mempengaruhi prestasi belajar yaitu: motivasi belajar peserta didik, gaya belajar, intensitas belajar, kondisi, tempat belajar, dan target belajar. Faktor eksternal yang mempengaruhi prestasi belajar salah satunya ketersediaan sarana prasarana pembelajaran (Slameto, 2010: 54).

Menurut Djamarah \& Azwar (2002: 19), "Prestasi adalah suatu kegiatan yang telah dikerjakan, diciptakan baik secara individual maupun kelompok". Berdasarkan pendapat di atas dapat disimpulkan bahwa prestasi belajar merupakan hasil usaha peserta didik yang dapat dicapai berupa penguasan pengetahuan, kemampuan kebiasaan dan keterampilan serta sikap setelah mengikuti proses pembelajaran yang dapat dibuktikan dengan hasil tes.

Menurut Hariyanto (2014: 28) Indikator keberhasilan suatu proses belajar mengajar tersebut adalah:

1. Daya serap terhadap bahan pengajaran yang diajarkan mencapai prestasi tinggi, baik secara individu maupun kelompok.

2. Perilaku yang digariskan dalam kompetensi dasar telah dicapai oleh peserta didik, baik secara individu maupun secara kelompok.

Sedangkan Indikator prestasi belajar menurut Syah (2010: 150-152) "Indikator prestasi belajar adalah hasil belajar yang meliputi segenap ranah pesikologis yang berubah akibat pengalaman dan proses belajar peserta didik, ranah cipta (psikologis), ranah rasa (afektif), ranah karsa (psikomotor)". Indikator prestasi belajar menurut Syah adalah sebagai berikut:

1. Ranah Cipta (kognitif) diantaranya peserta didik dapat menunjukkan, membandingkan, menghubungkan, menyebutkan, menjelaskan, mendefinisikan dan memberikan contoh.

2. Ranah Rasa (afektif) diantaranya peserta didik dapat menunjukkan sikap menerima, menunjukkan sikap menolak, mengakui dan menyakiti, mengingkari, dan menjelmakan dalam pribadi dan perilaku sehari-hari.

3. Ranah Karsa (psikomotor) diantaranya peserta didik dapat mengkoordinirkan gerak mata, kaki dan anggota tubuh lainnya, mengucapkan, membuat mimik dan gerak jasmani. 
Tiga ranah ini dijadikan peserta didik untuk dasar kemampuan yang harus dicapai dalam proses pembelajaran. Hakikatnya prestasi belajar merupakan perubahan tingkah laku dan pola pikir peserta didik dalam hal yang lebih baik. Proses pembelajaran dapat dikatakan berhasil apabila peserta didik mengalami peningkatan pada ranah kognitif, afektif dan psikomotor.

Namun ketersediaan sarana prasarana di SMP N 3 Kaloran belum memadai, sehingga proses pembelajaran belum maksimal, selain itu beberapa peserta didik yang beragama Buddha di SMP N 3 Kaloran pasif, kurang motivasi, tidak mengetahui tujuan belajar yang akan dicapai, dan minat belajarnya rendah, hal ini dapat mengakibatkan prestasi belajar peserta didik rendah. Keaktifan peserta didik dalam proses pembelajaran merupakan hal yang sangat penting dan perlu diperhatikan sehingga proses pembelajaran dapat berjalan optimal.

\section{METODE}

Penelitian ini mengunakan metode kuantitatif ex-post facto. Metode kuantitatif dapat diartikan sebagai metode penelitian yang berlandasan pada filsafat positivisme, digunakan untuk meneliti pada populasi atau sampel tertentu, pengumpulan data menggunakan instrumen penelitian, analisis data bersifat kuantitatif atau statistika, dengan tujuan untuk menggambarkan dan menguji hipotesis yang telah ditetapkan (Sugiyono, 2018: 15). Sedangkan ex-post facto menurut Arikunto (2013: 17) merupakan penelitian tentang variabel yang fakta atau kejadiannya telah terjadi sebelum penelitan dilakukan.

Menggunakan metode kuantitatif ex-post facto yaitu data yang digunakan sudah dilaksanakan, dan ingin mengetahui pengaruh ketersediaan sarana prasarana dan keaktifan peserta didik terhadap prestasi belajarPenelitian dilakukan pada peserta didik beragama Buddha di SMP N 3 Kaloran. Teknik pengambilan data kuantitatif diperoleh dari kuesioner atau angket dan observasi, sebelum angket diberikan kepada responden angket di uji cobakan terlebih dahulu di luar responden sebenarnya. Tujuan dari uji coba angket yaitu untuk mengetahui validitas dan reliabilitas, Pengujian reliabilitas dalam penelitian ini menggunakan komputer dengan program SPSS For Windows Realease 25. Pertanyaan dalam kuesioner dikatakan reliabel jika nilai pada Cronbach's alpha adalah $(>0,6)$ (Arikunto, 2013: 195) yang dirumuskan sebagai berikut:

$$
r_{n}=\left[\frac{k}{k-1}\right]\left[1-\frac{\sum a b^{2}}{a b^{2}}\right]
$$

Keterangan:

$\mathrm{r}_{\mathrm{n}} \quad=$ Reliabilitas instrumen

$\mathrm{k}=$ =Banyaknya butir pertanyaan

$\sum \mathrm{ab}_{2} \quad=$ jumlah varian butir

$\mathrm{ab}_{2} \quad=$ Varian total

Reliabilitas variabel dapat dikatakan reliabel apabila:

a. Reliabilitas uji coba $>0,60$ berarti hasil uji coba memiliki reliabilitas baik.

b. Reliabilitas uji coba $\leq 0,60$ berarti hasil uji coba memiliki reliabilitas kurang baik.

\section{HASIL}

\section{A. Hasil Analisis}

1. Uji Persial Atau Uji t Pengaruh Ketersediaan Sarana Prasarana Pembelajaran Terhadap Prestasi Belajar Mata Pelajaran Pendidikan Agama Buddha Di SMP N 3 Kaloran 
Tabel 1. Koefisien Regresi

\begin{tabular}{|c|c|c|c|c|c|c|}
\hline \multicolumn{7}{|c|}{ Coefficients $^{\mathrm{a}}$} \\
\hline \multirow{2}{*}{\multicolumn{2}{|c|}{ Model }} & \multicolumn{2}{|c|}{$\begin{array}{c}\text { Unstandardiz } \\
\text { ed } \\
\text { Coefficients }\end{array}$} & $\begin{array}{c}\text { Sta } \\
\text { nda } \\
\text { rdi } \\
\text { zed } \\
\text { Co } \\
\text { effi } \\
\text { cie } \\
\text { nts }\end{array}$ & \multirow[b]{2}{*}{$\mathrm{T}$} & \multirow[b]{2}{*}{ Sig. } \\
\hline & & $\mathrm{B}$ & $\begin{array}{l}\text { Std. } \\
\text { Error }\end{array}$ & $\begin{array}{c}\text { Bet } \\
\text { a }\end{array}$ & & \\
\hline 1 & $\begin{array}{l}\text { (Co } \\
\text { nsta } \\
\text { nt) }\end{array}$ & $\begin{array}{r}41,0 \\
28\end{array}$ & 12,680 & & 3,236 &, 002 \\
\hline & $\mathrm{x} 1$ & ,116 & ,069 & $\begin{array}{r}24 \\
2 \\
\end{array}$ & 1,682 &, 100 \\
\hline & $\mathrm{x} 2$ & ,164 & ,046 & $\begin{array}{r}, 51 \\
2\end{array}$ & 3,558 & ,001 \\
\hline
\end{tabular}

(Sumber: Primer, diolah: 2020)

Berdasarkan hasil analisis dengan program SPSS yang digunakan untuk mengetahui apakah ada pengaruh ketersediaan sarana prasarana pembelajaran terhadap prestasi belajar mata pelajaran Pendidikan Agama Buddha di SMP N 3 Kaloran. Untuk mengetahui pengaruh tersebut yakni dengan menguji hipotesis yang telah ditetapkan. Adapun hipotesisnya adalah:

Ho1: Tidak terdapat pengaruh yang signifikan pada ketersediaan sarana prasarana pembelajaran terhadap prestasi belajar mata pelajaran Pendidikan Agama Buddha di SMP N 3 Kaloran.

Ha1: Terdapat pengaruh yang signifikan pada ketersediaan sarana prasarana pembelajaran terhadap prestasi belajar mata pelajaran Pendidikan Agama Buddha di SMP N 3 Kaloran

Dalam pengujian hipotesis dengan cara menggunakan uji $\mathrm{t}$ hitung dengan $\mathrm{t}$ tabel. T tabel diperoleh dengan ketentusn taraf signifikan 0,05 dan derajad kebebasan (dk) dengan ketentuan: $\mathrm{dk}=(\mathrm{n}-2)$ atau (45$2)=43$. Dari ketentuan tersebut diperoleh $t$ tabel sebesar 1,681 Jika thitung lebih besar dari t tabel maka Hol ditolak dan Hal diterima, jika t hitung lebih kecil dari $t$ tabel maka Ho1 diterima dan Ha1 ditolak.

Berdasarkan hasil perhitungan diperoleh t hitung sebesar 1,1682 Angka 1,1682 > 1,681, sehingga Ho1 ditolak dan Ha1 diterima. Deskripsi tersebut mendefinisikan bahwa terdapat pengaruh ketersediaan sarana prasarana pembelajaran terhadap prestasi belajar peserta didik mata pelajaran pendidikan Agama Buddha di SMP N 3 Kaloran. Besarnya pengaruh ketersediaan sarana prasaran pembelajaran terhadap prestasi belajar peserta didik sebesar 0,116 . Artinya jika ketersediaan sarana prasarana pembelajaran naik satu satuan dengan asumsi variabel lain konstan atau nol maka prestasi belajar peserta didik akan naik sebesar 0,116 .

2. Uji Persial Atau Uji $T$ Pengaruh Keaktifan Peserta Didik Terhadap Prestasi Belajar Mata Pelajaran Pendidikan Agama Buddha Di SMP N 3 Kaloran

Berdasarkan hasil analisis yang digunakan untuk mengetahui apakah ada pengaruh keaktifan peserta didik terhadap prestasi belajar mata pelajar Pendidikan Agama Buddha di SMP N 3 Kaloran. Untuk mengetahui pengaruh tersebut yakni dengan menguji hipotesis yang telah 
ditetapkan. Adapun hipotesisnya sebagai berikut:

Ho2: Tidak terdapat pengaruh yang signifikan pada keaktifan peserta didik terhadap prestasi belajar mata pelajaran Pendidikan Agama Buddha di SMP N 3 Kaloran.

Ha2: Terdapat pengaruh yang signifikan pada keaktifan peserta didik terhadap prestasi belajar mata pelajaran Pendidikan Agama Buddha di SMP N 3 Kaloran.

Dalam pengujian hipotesis dengan cara menggunakan uji $\mathrm{t}$ hitung dengan $\mathrm{t}$ tabel. $\mathrm{T}$ tabel diperoleh dengan ketentuan taraf signifikan 0,05 dan derajad kebebasan (dk) dengan ketentuan: $\mathrm{dk}=(\mathrm{n}-2)$ atau (45$2)=43$. Dari ketentuan tersebut diperoleh $t$ tabel sebesar 1.681 Jika t hitung lebih besar dari t tabel maka Ho2 ditolak dan $\mathrm{Ha} 2$ diterima, jika t hitung lebih kecil dari t tabel maka Ho2 diterima dan Ha2 ditolak.

Berdasarkan hasil perhitungan diperoleh $\mathrm{t}$ hitung sebesar 3,558 Angka $3,558>1,681$, sehingga Ho2 ditolak dan Ha2 diterima. Deskripsi tersebut mendefinisikan bahwa terdapat pengaruh keaktifan peserta didik terhadap prestasi belajar mata pelajaran Pendidikan Agama Buddha di SMP N 3 Kaloran. Besarnya pengaruh ketersediaan sarana prasaran pembelajaran terhadap prestasi belajar peserta didik sebesar 0,164. Artinya jika ketersediaan sarana prasarana pembelajaran naik satu satuan dengan asumsi variabel lain konstan atau nol maka prestasi belajar peserta didik akan naik sebesar 0,164.
3. Uji Simultan atau Secara Bersama-Sama (Uji F) Pengaruh Ketersediaan Sarana Prasarana Pembelajaran dan Keaktifan Peserta Didik terhadap Prestasi Belajar Mata Pelajaran Pendidikan Agama Buddha Di SMP N 3 Kaloran

Tabel 2. Anova

\begin{tabular}{|c|c|c|c|c|c|c|}
\hline \multicolumn{7}{|c|}{ ANOVA $^{a}$} \\
\hline \multicolumn{2}{|c|}{ Model } & $\begin{array}{c}\text { Sum } \\
\text { of } \\
\text { Squar } \\
\text { es }\end{array}$ & Df & $\begin{array}{c}\text { Mean } \\
\text { Squa } \\
\text { re }\end{array}$ & $\mathrm{F}$ & Sig. \\
\hline \multirow[t]{3}{*}{1} & $\begin{array}{l}\text { Regre } \\
\text { ssion }\end{array}$ & $\begin{array}{r}252,3 \\
73 \\
\end{array}$ & 2 & $\begin{array}{r}126,1 \\
86 \\
\end{array}$ & $\begin{array}{r}6,4 \\
41 \\
\end{array}$ &, $004^{b}$ \\
\hline & $\begin{array}{l}\text { Resid } \\
\text { ual }\end{array}$ & $\begin{array}{r}822,8 \\
72 \\
\end{array}$ & 42 & $\begin{array}{r}19,59 \\
2 \\
\end{array}$ & & \\
\hline & Total & $\begin{array}{r}1075 \\
244 \\
\end{array}$ & 44 & & & \\
\hline \multicolumn{7}{|c|}{ a. Dependent Variable: y } \\
\hline \multicolumn{7}{|c|}{ b. Predictors: (Constant), $\mathrm{x} 2, \mathrm{x} 1$} \\
\hline
\end{tabular}

(Sumber: Primer, diolah: 2020)

Berdasarkan uji $\mathrm{F}$ di atas digunakan untuk mengetahui pengaruh ketersediaan sarana prasarana pembelajaran dan keaktifan peserta didik terhadap prestasi belajar mata pelajaan Pendidikan Agama Buddha di SMP N 3 Kaloran.

Hipotesis:

Ha3: Tidak terdapat pengaruh ketersediaan sarana prasarana pembelajaran dan keaktifan peserta didik terhadap prestasi belajar mata pelajaran Pendidikan Agama Buddha di SMP N 3 Kaloran

Ho3: Terdapat pengaruh ketersediaan sarana prasarana pembelajaran dan keaktifan peserta didik terhadap prestasi belajar mata pelajaran Pendidikan Agama Buddha di SMP N 3 Kaloran.

Pengujian hipotesis dilakukan dengan membandingkan $\mathrm{F}$ hitung dengan $\mathrm{F}$ tabel dan juga membandingkan taraf signifikasi 
$5 \%(\alpha=0,05)$. Jika $f$ hitung lebih besar dari f tabel maka Ha3 diterima dan Ho3 ditolak. Jika f hitung lebih kecil dari $\mathrm{f}$ tabel maka Ha3 ditolak dan Ho3 diterima. Dari tabel di atas diperoleh bahwa $\mathrm{f}$ hitung lebih besar dari f tabel yaitu $6,441>3,22$, artinya Ha3 diterima dan Ho3 ditolak. Nilai probabilitas dikatakan signifikan apabila nilai probabilitas signifikansi lebih kecil daripada taraf signifikan (sig. $<\alpha$ ) maka Ha3 diterima dan Ho3 ditolak. Jika nilai probabilitas dikatakan signifikan apabila nilai probabilitas signifikansi lebih besar daripada taraf signifikan (sig. $>\alpha$ ) Ha3 ditolak dan Ho3 diterima. Dari tabel di atas terlihat bahwa nilai probabilitas signifikan lebih besar daripada taraf signifikan $(0,004$ $<0,05)$ maka hipotesis Ha3 diterima karena ada pengaruh simultan dan signifikan antara ketersediaan sarana prasarana pembelajaran dan keaktifan peserta didik terhadap prestasi belajar. Sedangkan untuk mengetahui besarnya pengaruh ketersediaan sarana prasarana pembelajaran dan keaktifan peserta didik mata pelajaran Pendidikan Agama Buddha di SMP N 3 Kaloran terlihat pada tabel di bawah ini.

Tabel 3.Model Summary

\begin{tabular}{|l|c|c|c|c|}
\hline \multicolumn{5}{|c|}{ Model Summary } \\
\hline & & & & $\begin{array}{c}\text { Std. } \\
\text { Error } \\
\text { Mo }\end{array}$ \\
del & R & $\begin{array}{c}\text { R } \\
\text { Squa } \\
\text { re }\end{array}$ & $\begin{array}{c}\text { Adjust } \\
\text { ed R } \\
\text { Square }\end{array}$ & $\begin{array}{c}\text { Estimat } \\
\text { e }\end{array}$ \\
\hline 1 &, 48 &, 235 &, 198 & 4,426 \\
& 4 & & & \\
\hline \multicolumn{4}{|c|}{ a. Predictors: (Constant), x2, x1 } \\
\hline
\end{tabular}

(Sumber: Primer, diolah: 2020)
Pada tabel di atas terlihat bahwa angka R Square adalah 0,235. Angka tersebut mempunyai arti bahwa pengaruh ketersediaan sarana prasarana pembelajaran dan keaktifan belajar terhadap prestasi belajar mata pelajaran Pendidikan Agama Buddha secara simultan sebesar 23,5\%, sementara pengaruh sebesar 76,5\% disebabkan oleh variabel-variabel lain diluar model ini.

\section{B. Pembahasan}

\section{Pengaruh Ketersediaan Sarana Prasarana} Pembelajaran Terhadap Prestasi Belajar Mata Pelajaran Pendidikan Agama Buddha Di SMP N 3 Kaloran

Berdasarkan hasil analisis data dan observasi yang telah dilakukan. Dapat diungkap pembahasan penelitian pengaruh ketersediaan sarana prasarana pembelajaran dan keaktifan peserta didik terhadap prestasi belajar mata pelajaran Pendidikan Agama Buddha di SMP N 3 Kaloran, sebagai berikut: hasil penelitian diperoleh $\mathrm{t}$ hitung sebesar 1 , 682. Angka 1,682 > 1,681, sehingga Ho1 ditolak dan Hal diterima. Deskripsi tersebut mendefinisikan bahwa terdapat pengaruh ketersediaan sarana prasarana pembelajaran terhadap prestasi belajar peserta didik mata pelajaran pendidikan Agama Buddha di SMP N 3 Kaloran sebesar 0,116. Artinya ketersediaan sarana prasarana pembelajaran terdapat pengaruh terhadap prestasi belajar.

Berdasarkan hasil analisis data dapatdinyatakan bahwa terdapat pengaruh yang signifikan ketersediaan sarana prasarana pembelajaran terhadap prestasi belajar. Seperti yang diketahui bahwa sarana 
prasarana pembelajaran merupakan peralatan yang dapat digunakan secara langsung dan menunjang proses pembelajaran, seperti meja, kursi, papan tulis, buku, ruang kelas dan media-media pembelajaran. Hal ini sesuai dengan teori yang disampaikan oleh Sanjaya (2010: 18) yang menyatakan bahwa sarana belajar adalah segala sesuatu yang mendukung terhadap kelancaran proses pembelajaran.

\section{Pengaruh keaktifan peserta didik} Terhadap Prestasi Belajar Mata Pelajaran Pendidikan Agama Buddha Di SMP N 3 Kaloran

Berdasarkan hasil perhitungan diperoleh $\mathrm{t}$ hitung sebesar 3,558. Angka 3,558 > 1,681, sehingga Ho2 ditolak dan Ha2 diterima. Deskripsi tersebut mendefinisikan bahwa terdapat pengaruh keaktifan peserta didik terhadap prestasi belajar mata pelajaran Pendidikan Agama Buddha di SMP Negeri 3 Kaloran. Besarnya pengaruh ketersediaan sarana prasaran pembelajaran terhadap prestasi belajar peserta didik sebesar 0,164.

Hasil uji yang menyatakan keaktifan peserta didik terdapat pengaruh yang signifikan terhadap prestasi belajar. Seperti yang diketahui bahwa keaktifan peserta didik dapat meningkatkan prestasi belajar, peserta didik yang aktif bertanya, menulis, membaca, mengerjakan soal, artinya peserta didik tersebut memiliki rasa ingin tahu yang tingg, dengan demikian pengetahuan peserta didik semakin berkembang. hal ini juga diperkuat oleh teori yang disampaikan oleh Rizwani dan Widayati (2012: 7) Keaktifan belajar peserta didik adalah aktifitas peserta didik dalam proses belajar mengajar yang melibatkan kemampuan emosional dan lebih menekankan pada kreativitas peserta didik, meningkatkan kemampuan, serta mencapai peserta didik yang kreatif dan mampu menguasai konsep-konsep.

Selain itu menurut Slameto (2010: 54) terdapat dua faktor yang mempengaruhi prestasi belajar yaitu faktor internal dan faktor eksternal. Faktor eksternal dari luar diri peserta didik, dan faktor internal dari dalam diri peserta didik. faktor eksternail diantaranya: sekolah, keluarga dan lingkungan masyarakat, sedangkan faktor internal dianataranya: gaya belajar, minat, bakat, motivasi, semangat, keaktifan dan perhatian.

Sedangkan menurut Sudjana (2005: 72) keaktifan peserta didik dapat dilihat dari keikutsertaan peserta didik dalam melaksanakan tugas belajarnya, terlibat dalam memecahkan masalah, bertannya kepada peserta didik lain atau guru apabila tidak memahami persoalan yang dihadapi, berusaha mencari berbagai informasi yang diperlukan untuk memecahkan masalah, melatih diri dalam memecahkan masalah atau soal, serta menilai kemampuan diri sendiri dan hasil-hasil yang diperoleh.

3. Pengaruh Ketersediaan Saran Prasarana Pembelajaran dan Keaktifan Peserta Didik Terhadap Prestasi Belajar Mata Pelajaran Pendidikan Agamza Buddha Di SMP N 3 Kaloran

Berdasarkan hasil penelitian yang telah dilakukan menunjukkan $\mathrm{f}$ hitung lebih besar dari $f$ tabel yaitu $6,441>3,22$. Nilai 
probabilitas dikatakan signifikan apabila nilai probabilitas signifikansi lebih kecil daripada taraf signifikan ( sig. $<\alpha$ ) maka Ha3 diterima dan Ho3 ditolak. Jika nilai probabilitas dikatakan signifikan apabila nilai probabilitas signifikansi lebih besar daripada taraf signifikan (sig. $>\alpha$ ) Ha3 ditolak dan Ho3 diterima.

Berdasarkan tabel 4.10 terlihat bahwa nilai probabilitas signifikan lebih besar daripada taraf signifikan $(0,004<0,05)$ maka hipotesis $\mathrm{Ha} 3$ diterima karena ada pengaruh simultan dan signifikan antara ketersediaan sarana prasarana pembelajaran dan keaktifan peserta didik terhadap prestasi belajar. Sedangkan angka R Square adalah 0,235. Angka tersebut mempunyai arti bahwa pengaruh ketersediaan sarana prasarana pembelajaran dan keaktifan belajar terhadap prestasi belajar mata pelajaran Pendidikan Agama Buddha secara simultan sebesar $23,5 \%$, sementara pengaruh sebesar $76,5 \%$ disebabkan oleh variabel-variabel lain diluar model ini.

Hasil hitung regresi linear diperoleh persamaan: $\mathrm{Y}=41,028+0,116\left(\mathrm{X}_{1}\right)+0,\left(\mathrm{X}_{2}\right)$ + e. Model ini berasumsi bahwa jika variabel ketersediaan sarana prasarana pembelajaran $\left(\mathrm{X}_{1}\right)$ dan keaktifan peserta didik $\left(\mathrm{X}_{2}\right)$ adalah 0 , maka variabel prestasi belajar (Y) mata pelajaran pendidikan Agama Buddha di SMP N 3 Kaloran sebesar 41,028. Asumsi lain adalah jika variabel ketersediaan sarana prasarana pembelajaran $\left(\mathrm{X}_{1}\right)$ mengalami kenaikan satu satuan variabel lainnya tetap, maka variabel prestasi belajar (Y) mata pelajaran Pendidikan Agama Budda di SMP N 3 Kaloran mengalami kenaikan sebesar
0,116 dan variabel keaktifan peserta didik $\left(\mathrm{X}_{2}\right)$ mengalami kenaikan. Jika variabel keaktifan peserta didik $\left(\mathrm{X}_{2}\right)$ mengalami kenaikan satu satuan variabel lainnya tetap, maka variabel prestsi belajar (Y) mata pelajaran Pendidikan Agama Buddha di SMP Negeri 3 Kaloran mengalami kenaikan sebesar 0,164.

Sarana prasarana pembelajaran merupakan perlengkapan yang dapat langsung digunakan dan menujang proses belajar mengajar, seperti kepiawaian Sang Buddha dalam menggunakan sarana prasarana pembelajaran terdapat dalam kisah Culapanthaka. Dikisahkan seorang Bhikkhu yang bernama Culapanthaka yang kurang pandai dalam mengingat meskipun hanya satu syair dalam empat bulan. Sang Buddha mengerti akan kondisi Culapanthaka kemudian memberi satu potong kain putih dan meminta Bhikkhu Culapanthaka menggosok-gosok dengan tangannya. Bikkhu Culapanthaka menuruti petunjuk Sang Buddha dan akhirnya mencapai tingkat kesucian Arahat dengan menyadari bahwa "batin yang bersih dapat menjadi kotor karena ketamakan, kebencian dan ketidaktahuan" seperti halnya kain putih yang digosok-gosok dan menjadi kotor.

Dalam kisah Culapanthaka kain merupakan sarana Sang Buddha untuk memudahkan Culapanthaka dalam mencapai kesucian. Seperti halnya sarana prasaran pembelajaran seperti buku, papan tulis, meja dan kursi merupakan sarana prasarana yang mendukung proses pembelajaran. Menurut Mulyasa (2003: 49) Sarana pendidikan adalah peralatan dan perlengkapan yang 
secara langsung dipergunakan dan menunjang proses pendidikan, khususnya proses belajar mengajar, seperti gedung, ruangan kelas, meja, kursi, serta alat-alat dan media pengajaran. Barnawi (2012: 47-48), berpendapat bahwa prasarana pendidikan adalah semua perangkat kelengkapan dasar yang secara tidak langsung menunjang pelaksanaan proses pendidikan di sekolah.

Selain itu menurut Dimyati dan Mujiono (2013:51) bahwa keaktifan merupakan hal penting dalam kegiatan belajar, peserta didik dituntut untuk aktif. Dengan keaktifan peserta didik dapat meningkatkan semangat belajar selain itu memiliki pengetahuan luas. Seperti sabda Sang Buddha pada Mangala Sutta yaitu, Bahusaccanca sipppanca, vinayo ca susikkhito, subhasita ca ya vaca, etammangalamuttamam, artinya memiliki pengetahuan luas dan berketrampilan terlatih baik dalam tata susila ramah tamah dalam ucapan itulah berkah utama.

\section{Kesimpulan}

Berdasarkan hasil penelitian dan pembahassan yang telah dipaparkan di atas pada bab-bab sebelumnya, maka dapat diambil kesimpulan sebagai berikut:

1. Berdasarkan hasil perhitungan analisis regresi dari indikator variabel $\mathrm{X}_{1}$ (ketersediaan sarana prasarana pembelajaran) melalui SPSS, terdapat pengaruh ketersediaan sarana prasarana pembelajaran terhadap prestasi belajar peserta didik mata pelajaran Pendidikan Agama Buddha di SMP N 3 Kaloran sebesar 0,116. Dalam penelitian ini ketersediaan sarana prasarana terdapat pengaruh yang signifikan pada prestasi belajar.

2. Berdasarkan hasil perhitungan analisis regresi dari indikaor variabel $\mathrm{X}_{2}$ (keaktifan peserta didik) melalui SPSS, terdapat pengaruh keaktifan peserta didik terhadap prestasi belajar mata pelajaran Pendidikan Agama Buddha di SMP N 3 Kaloran sebesar 0,164 .

3. Berdasarkan analisis regresi linier berganda, terdapat pengaruh ketersediaan sarana prasarana pembelajaran dan keaktifan peserta didik terhadap prestasi belajar mata pelajaran Pendidikan Agama Buddha di SMP N 3 Kaloran dengan diperoleh besarnya R Square 0,235 . Angka tersebut mempunyai arti bahwa pengaruh ketersediaan sarana prasarana pembelajaran dan keaktifan peserta didik terhadap prestasi belajar sebesar 23,5\%, sementara $76,5 \%$ dipengaruhi oleh variabel lain diluar model ini.

\section{Saran}

1. Bagi peserta didik

Diharapkan peserta didik beragama Buddha lebih tekun dan aktif pada saat proses pembelajaran di sekolah maupun di rumah karena keaktifan peserta didik sangat penting. Semangat dan keaktifan dalam belajar harus di tingkatkan.

2. Bagi guru Pendidikan Agama Buddha

a. Diharapkan guru Pendidikan Agama Buddha menghimbau kepada peserta didik untuk aktif bertanya dan mencari informasi terkait materi pelajaran Pendidikan Agama Buddha.

b. Diharapkan guru Pendidikan Agama Buddha menghimbau kepada peserta didik 
untuk aktif terlibat dalam proses

Pendidikan Agama Buddha.

3. Bagi Sekolah

Bagi sekolah diharapkan untuk menyediakan sarana prasarana sesuai standar pendidikan nasional.

4. Bagi peneliti selanjutnya

a. Bagi peneliti selanjutnya hasil penelitian ini dapat dijadikan bahan referensi terkait ketersediaan sarana prasarana pembelajaran dan keaktifan peserta didik mata pelajaran Pendidikan Agama Buddha.

b. Bagi peneliti selanjutnya seyogyanya meneliti lebih mendalam terkait variabelvariabel yang dapat mempengaruhi prestasi belajar peserta didik mata pelajaran Pendidikan Agama Buddha.

c. Bagi peneliti selanjutnya diharapkan untuk meneliti faktor-faktor lain yang mempengaruhi prestasi belajar yang dapat memberikan manfaat di dunia pendidikan. Secara khusus perlu adanya perbaikan dalam teknik pengambilan data mengenai keaktifan peserta didik mengunakan lembar wawancara kiranya lebih di anjurkan guna menghindari kesalahan pengukuran.

\section{Daftar Pustaka}

Arikunto, S. (2013). Prosedur Penelitian Suatu Pendekatan Praktik. Jakarta: Rineka Cipta.

Barnawi \& Arifin, M. (2012). Manajemen Sarana dan Prasarana Sekolah. Jogjakarta. ArRuzz.

Dimyati \& Mudjiono. (2013). Belajar Dan Pembelajaran. Jakarta: Rineka Cipta.

Djamarah \& Azwan, Z (2002). Strategi Belajar Mengajar. Jakarta: PT. Rineka Cipta.
Hariyanto. (2014). Pengaruh Perhatian Peserta Didik dalam Pembelajaran terhadap Prestasi Belajar Pendidikan Agama Buddha di Kabupaten Wonogiri Tahun 2014. Wonogiri. Penelitan Dosen

Karsan \& Sulan. (2017). Buku Guru Pendidikan Agama Buddha dan Budi Pekerti. Jakarta: pusat kurikulun dan perbukuan, Balitbang, Kemendikbud.

Martinia, Y. (2007). Kiat Membelajarkan Siswa. Jakarta: Gaung Persada Press Dan Center For Learning Innovation (Cli).

Mulyasa, E. (2003). Menjadi Guru Profesional. Bandung: PT. Remaja Rosdakarya

Musfah, J. (2015). Peningkatan Kompetensi Guru Melalui Pelatihan dan Sumber Belajar Teori dan Praktis. Jakarta: PRENADAMEDIA GROUP.

Redaksi Sinar Grafika. (2014). Undang-undang SISDIKNAS (sistem pendidikan nasional) UU RI No. 20 Th. 2003. Jakarta: Sinar Grafika

Rizwani, \& Widayati. (2012). Model Active Learning Dengan Teknik Learning Starts With A Question Dalam Peningkatan Keaktifan Peserta Didik Pada Pembelajaran Akuntansi Kelas Xi Ilmu Sosial 1 Sma Negeri 7 Yogyakarta Tahun Ajaran 2011/2012. Vol. X, No. 2.

Rusidi. (2009). UNDANG-UNDANG SITEM PENDIDIKAN NASIONAL (Pendidikan Umum Dan Pendidikan Keagamaan). Jakarta: CV. NAGA JAWA BERDIKARI.

Sanjaya, W. (2010). Kurikulum Dan Pembelajaran: Teori dan Praktik Pengemabangan Kurikulum Tingkat Satuan Pendidikan (KTSP). Jakarta: Kencana Prenada Media Group.

Slameto. (2010). Belajar Dan Faktor-Faktor Yang Mempengaruhi. Edisi Revisi. Jakarta: Rineka Cipta.

Sudjana, N. (2004). Dasar - Dasar Proses Belajar Mengajar. Bandung: PT Remaja Rosdakarya.

(2005). Hasil Dan Proses Belajar Mengajar. Bandung: Remaja Rosdakarya. 
Syah, M. (2010). Pesikologi Pendidikan Dengan Pendekatan Baru. Bandung: PT. Remaja Rosdakarya

Wicaksono. P. (2012). Pengaruh Fasilitas Belajar, Motivasi Velajar, Dan Minat Belajar Terhadap Prestasi Belajar Siswa Kelas X SMK Muhamadiyah Prambanan Tahun Ajaran 2011/2012. Yogyakarta: Skripsi Universitas Negeri Yogyakarta.

Widiyanto, J. (2010). SPPSS For Windows. Surakarta: Badan Penerbit-FKUB Universitas Muhamadiyah Surakarta.

Yudi, A. (2012). Pengembangan mutu pendidikan diyinjau dari sarana dan prasarana (sarana dan prasarana PPLP) (Cerdas Sifa). No. 1. Hal 1-9. Padang: Jurnal FIK UNP Padang. (diakses Jumat, 15 November 2019. 12.00 WIB) 